\title{
Spatial Dynamics of Sulphate-reducing Bacterial Compositions in Sediment along a Salinity Gradient in a UK Estuary
}

\author{
Ryuji Kondo ${ }^{1 *}$, Kevin J. Purdy², Silvana de QueIroz Silva ${ }^{3}$ and David B. Nedwell ${ }^{4}$ \\ ${ }^{1}$ Department of Marine Bioscience, Fukui Prefectural University, Obama, Fukui 917-0003, Japan \\ ${ }^{2}$ Department of Biological Sciences, Gibbet Hill, University of Warwick, Coventry CV4 7AL, United Kingdom \\ ${ }^{3}$ Department of Environmental and Sanitary Engineering, Federal University of Minas Gerais, 30110-060 Belo \\ Horizonte, $M G$, Brazil \\ ${ }^{4}$ Department of Biological Sciences, University of Essex, Wivenhoe Park, Colchester CO4 3SQ, United Kingdom
}

(Received September 20, 2006-Accepted November 7, 2006)

The diversity of sulphate-reducing bacteria (SRB) was investigated in sediments along environmental gradients in the River Colne estuary, Essex, UK. DNA samples were collected from four sites; marine-dominated (Alresford Creek), brackish (the Hythe), predominantly freshwater (East Hill Bridge) and freshwater (the Weir) between September 2001 and May 2002. SRB community composition was assessed by PCR amplification, cloning and sequencing of part of the $\alpha$ subunit of dissimilatory sulphite reductase $(d s r A)$ using directly extracted sediment DNA. The majority of the $d s r A$ sequences were associated with members of the Desulfobacteraceae family, the Desulfobulbaceae family and a deeply branched group in the $d s r A$ tree with no cultured representatives. There was some evidence of a salinity-related distribution within both the Desulfobacteraceae and Desulfobulbaceae groups. Clones related to Desulfotomaculum of the xenologues Firmicutes and a phylogenetically distinct Colne group 3 were detected only at the freshwater East Hill Bridge and Weir sites. Conversely, clones related to an uncultured group (Colne group 1) were found only at the marine and brackish sites. A statistical analysis of composition revealed that $d s r A$ sequences from the marine-dominated Alresford Creek and the brackish site at the Hythe were not significantly different from each other $(P>0.05)$, but were significantly different from those of the freshwater-dominated East Hill Bridge and the Weir $(P<0.05)$. The sequences from East Hill Bridge and the Weir were not significantly different from each other $(P>0.05)$. The data presented show a complex distribution of SRB along the estuary with some evidence to support the idea that salinity and sulphate concentrations are an important factor in determining SRB community structure.

Key words: dissimilatory sulphite reductase gene, environmental gradients, estuarine sediment, sulphate reduction

Sulphate reduction is an important process involved in both the global carbon and sulphur cycles. This process can dominate anaerobic terminal mineralisation of organic matter in high-sulphate sediments, degrading up to $50 \%$ of all organic matter in coastal marine sediments ${ }^{12}$ and plays a minor but still important role in low-sulphate sediments ${ }^{26,38)}$. Rates of sulphate reduction vary in relation to temperature and electron donor and acceptor concentrations with the availability of sulphate an important factor in the control of

\footnotetext{
* Corresponding author. E-mail address: rykondo@fpu.ac.jp; Tel.: +81-770-52-9619; Fax: +81-770-52-6003.
}

the rate of sulphate reduction. Sulphate concentrations range from approximately $25 \mathrm{mM}$ in full-strength seawater to $<0.2 \mathrm{mM}$ in freshwater ${ }^{7)}$. Freshwater-adapted sulphatereducing bacteria (SRB) have a greater affinity for sulphate $\left(K_{\mathrm{m}}=5-68 \mu \mathrm{M}\right)$ than marine-adapted SRB $\left(K_{\mathrm{m}}=200 \mu \mathrm{M}\right)^{8,37)}$, allowing them to continue sulphate reduction at much lower sulphate concentrations than marine SRB. Physiological differences between freshwater- and marine-adapted SRB may be reflected in differences in species or phylogenetic compositions of SRB communities.

The Colne estuary is a small, muddy, macrotidal (3 to 5 $\mathrm{m}$ ) estuary on the east coast of England, entering the North 
Sea at Brightlingsea, Essex. The estuary catchment is 500 $\mathrm{km}^{2}$, of which the River Colne drains $300 \mathrm{~km}^{2}$, much of which is rich arable land. The Colne is hyper nutrified and there are pronounced gradients in concentrations of inorganic nutrients and organic carbon inversely related to the salinity gradient ${ }^{13,30,42)}$. We are currently using molecular methods to investigate the distribution of SRB and measure their activities in different sites along the salinity gradient in this well studied estuary ${ }^{15,31,34)}$. Using competitive PCR targeting the gene for parts of the $\alpha$ subunit of dissimilatory sulphite reductase $(d s r A)$ for enumeration of $\mathrm{SRB}$, it was demonstrated that SRB in the Colne estuary sediment were abundant with no distinct seasonal and spatial fluctuations ${ }^{15)}$. The specific activity of sulphate reduction in each bacterial cell differed site by site along the gradient in the estuary. A previous, limited phylogenetic analysis of $d s r A$ sequences was used to identify members of the SRB community in sediment at three sites with different salinities: Alresford Creek, predominantly seawater; the Hythe, brackish; and East Hill Bridge, at the top end of the River Colne estuary, predominantly freshwater but penetrated by seawater during very high tides ${ }^{15}$. These sequences suggested that SRB populations may differ under different environmental conditions.

Here, we have extended our phylogenetic description of the SRB in sediment of the Colne estuary increasing the number of clones in each library and including freshwater sediment at the Weir, ca. $200 \mathrm{~m}$ upstream of the East Hill Weir, which separates the tidal and non-tidal regions of the River Colne. The new $d s r A$ sequences were analysed together with sequences recovered previously from the Colne estuary on September 2001 and reference taxa.

\section{Materials and Methods}

\section{Sediment sampling}

Experiments were conducted with samples taken from the River Colne estuary, Essex, UK. Sediment samples were collected from four sites on the estuary along the saline gradient, Alresford Creek (predominantly seawater), the Hythe (brackish water), East Hill Bridge (predominantly freshwater with occasional incursions of seawater) and the Weir (freshwater). Sediment cores ( $8 \mathrm{~cm}$ i.d. $\times 12 \mathrm{~cm} \mathrm{long}$ ) were taken from September 2001 to May 2002 at three sites (Alresford Creek, the Hythe and East Hill Bridge) and from January to May 2002 at the Weir and were returned to the laboratory within two hours of sampling. Sediment temperature was measured by insertion of a thermometer to a depth of ca. $2.5 \mathrm{~cm}$.

\section{Sulphate reduction rates}

Rates of sulphate reduction were determined using a ${ }^{35} \mathrm{~S}$ sulphate radiotracer ${ }^{11)}$ in sediment minicores of the $0-4.5$ $\mathrm{cm}$ depth horizon taken from the sampling cores with 5-ml sterile syringes with the needle end cut off. Each sediment sample was injected with $25 \mu$ of sodium ${ }^{35} \mathrm{~S}$-sulphate solution $\left(1480 \mathrm{MBq} \mathrm{ml}^{-1}, 0.37-3.7 \mathrm{GBq} \mathrm{mmole}^{-1}\right.$ [GE Healthcare, Buckinghamshire, $\mathrm{UK}]$ ) and incubated at the in situ temperature for $5 \mathrm{~h}$. These samples were then fixed with 5 $\mathrm{ml}$ of $5 \%(\mathrm{w} / \mathrm{v})$ zinc acetate and stored at $-20^{\circ} \mathrm{C}$ until digested and analysed as described by Nedwell and Takii ${ }^{29)}$.

Sediment porewater was obtained by centrifugation at $6,000 \mathrm{~g}$ for $15 \mathrm{~min}$ at $4^{\circ} \mathrm{C}$. Sulphate concentrations in the porewater were determined by a DIONEX 2000i/SP ion chromatograph with an AS4A-SC column (Dionex, Sunnyvale, CA, USA). Porewater salinities were measured using a refractive salinometre (Leica model 10419, Buffalo, NY, USA).

\section{Extraction of nucleic acids from sediment samples}

The sample core was extruded and subsamples were taken over the top $0-4.5 \mathrm{~cm}$ horizon, using a $20-\mathrm{ml}$ polypropyrene hypodermic syringe with the needle end cut off. DNA was extracted by the hydroxyapatite spin-column method $^{32)}$. After a final ethanol precipitation the nucleic acid was resuspended in $50 \mu \mathrm{l}$ of TE buffer $(10 \mathrm{mM}$ Tris-HCl, 1 mM EDTA [pH 8.0]). One microlitre of a 10-fold dilution (in TE) of the extracted DNA was used in PCR.

\section{PCR amplification, cloning and sequencing}

All amplifications were performed using a single set of primers, DSR1F+ and DSR-R, which are specific for $d s r A$ genes of most mesophilic $\mathrm{SRB}^{15}$. The reaction mixture (50 $\mu \mathrm{l})$ used for PCR contained $0.2 \mathrm{mM}$ dNTPs, $3.5 \mathrm{mM} \mathrm{MgCl}_{2}$, $0.4 \mu \mathrm{M}$ of each primer, $1 \times \mathrm{PCR}$ buffer, $1 \times \mathrm{Q}$-solution, $2.5 \mathrm{U}$ of Taq DNA polymerase (Qiagen, Hilden, Germany) and $\sim 100 \mathrm{ng}$ of sediment DNA. The amplification was performed in a thermal cycler (PJ2400, Applied Biosystems, Foster City, CA, USA) as follows: initial denaturation at $94^{\circ} \mathrm{C}$ for $1 \mathrm{~min}$, then 30 cycles at $94^{\circ} \mathrm{C}$ for $30 \mathrm{sec}, 60^{\circ} \mathrm{C}$ for $30 \mathrm{sec}$ and $72^{\circ} \mathrm{C}$ for $60 \mathrm{sec}$ with the final elongation at $72^{\circ} \mathrm{C}$ for $7 \mathrm{~min}$.

After amplification of the DNA, unpurified $d s r A$ PCR products were cloned using a TA Cloning Kit (Invitrogen, Carlsbad, CA, USA) according to the manufacturer's instructions. Cloned inserts were reamplified using the vector primers M13 forward and reverse $\left(25\right.$ cycles of $94^{\circ} \mathrm{C}$ for $30 \mathrm{sec}, 50^{\circ} \mathrm{C}$ for $30 \mathrm{sec}$ and $72^{\circ} \mathrm{C}$ for $30 \mathrm{sec}$ ) and the result- 
ing PCR products were purified using Wizard SV Gel and PCR Clean-Up System (Promega, Madison, WI, USA) according to the manufacturer's instructions. Randomly selected clones were sequenced at Macrogen, Inc. (Seoul, Korea) using the M13 forward primer.

\section{Phylogenetic analysis}

The sequence corresponding to nucleotides 421-641 of Desulfovibrio vulgaris DSM 644 ${ }^{\mathrm{T}} d s r A$ was determined in this study. Primer sequences were excluded from phylogenetic analyses. Using CLUSTAL $\mathrm{X}^{40)}$, Colne estuary $d s r A$ clone sequences were aligned to $\operatorname{ds} A B$ sequences from known sulphate-reducing prokaryotes obtained from an ARB $d s r A B$ database available at http://www.microbialecology.net/download.asp ${ }^{44)}$. Maximum parsimony, minimum evolution and neighbour-joining analyses were performed using the MEGA software package, version 3.1 ${ }^{17}$. Confidence limits on the tree topologies were estimated by bootstrap analysis ${ }^{5)}$ with 1,000 replications. The branching pattern from these analyses was mostly consistent with that of trees generated based on a larger fragment from the $d s r A B$ operon ${ }^{15)}$, indicating that no significant biases were imposed by phylogenetic analyses of these shorter sequences. As the length of nucleotide sequences used to derive the $d s r A$ phylogeny was limited, the bootstrap values were generally lower than those seen in the $d s r A B$ tree.

\section{Statistical analysis and sequence diversity}

There is no consensus on how to distinguish species or genera based on $d s r A$ sequence similarity. In this study, we chose to use a relatively conservative value to discriminate at the genus level. Sequence similarities of the $d s r A$ region we have targeted did not exceed $85 \%$ between genera of cultured SRB cultures, and average sequence similarity among Desulfovibrio species was approximately $85 \%$. To assign a sequence to a distinct operational taxonomic unit (OTU), sequences with greater than $85 \%$ similarity were considered to represent the same OTU in this study. Thus, the taxa (OTU) that we define for the purpose of this analysis are probably distinct at least at the genus level.

Coverage $(C)$ was calculated by using the formula $C=1-$ $\left(n_{1} / N\right)$, where $n_{1}$ is the number of OTUs that occurred only once in the clone library and $N$ is the total number of clones analysed $^{24)}$. The phylogenetic compositions of libraries were compared by the use of the Sorensen similarity index, $C s=2 j /(a+b)$, where $j$ is the number of OTUs common to both samples and $a$ and $b$ are the numbers of OTUs in libraries A and B, respectively ${ }^{23}$. The statistical significance of differences in the compositions of pair of libraries was tested by using the LIBSHUFF programme ${ }^{36)}$.

\section{Nucleotide sequence accession numbers}

Partial cloned $d s r A$ sequences recovered from sediment of the Colne estuary were deposited in DDBJ under accession numbers AB271546 to AB271666. Only one representative sequence in each OTU was deposited.

\section{Results and Discussion}

\section{Sulphate concentrations and rates of sulphate reduction}

Porewater salinity of the Weir sediments was $<0.1 \mathrm{psu}$ and porewater sulphate concentrations ranged from 0.10 to $0.19 \mathrm{mM}$ during our investigation. These values are considerably lower than those at the other three sites in the Colne estuary (11.0-31.0 psu and 12.1-27.1 mM at Alresford Creek, $1.0-8.0$ psu and $1.7-8.0 \mathrm{mM}$ at the Hythe, and 0.0 $1.0 \mathrm{psu}$ and $0.3-1.5 \mathrm{mM}$ at East Hill Bridge $\left.{ }^{15}\right)$ ). The temperature of the surface sediment of the River Colne estuary ranged from 6.0 to $18.0^{\circ} \mathrm{C}$ during our investigation. High rates of sulphate reduction were measured at all four sites. Even in the low-sulphate environment of the Weir, rates (76.2-105.7 $\mathrm{nmol} \mathrm{ml}^{-1}$ day $^{-1}$ ) were comparable to those in high-sulphate environments at Alresford Creek (13.1-57.8 nmol ml ${ }^{-1}$ day $^{-1}$ ), the Hythe (17.6-193.4 $\mathrm{nmol} \mathrm{ml}^{-1}$ day $^{-1}$ ) and East Hill Bridge $\left(10.2-165.0 \mathrm{nmol} \mathrm{ml}^{-1} \text { day }^{-1}\right)^{15)}$. The rates at the Weir were within the range of those previously reported in eutrophic lakes ${ }^{6,9)}$, but higher than those in mesophilic lakes ${ }^{20,22)}$. The relatively high sulphate concentrations in the Weir sediments compared with other freshwater environments ${ }^{9,20,22)}$ may reflect high rates of sulphate reduction. The organic carbon content of the sediment in the River Colne estuary increases toward the top end of the estuary $^{42)}$ and this factor may have also resulted in the high in situ rates of sulphate reduction.

\section{Phylogenetic analyses}

In this study, we have extended our phylogenetic description of the SRB in sediment of the Colne estuary, increasing the number of clones from each of the three sediment libraries and including samples of freshwater sediment at the Weir. PCR amplification of $d s r A$ using the primers DSR1F+ and DSR-R resulted in products of predicted size $(221 \mathrm{bp})$ from the sediment samples. A total of 350 clones (113 clones from Alresford Creek, 101 from the Hythe, 94 from East Hill Bridge and 42 from the Weir) were sequenced. These 350 clones comprised 292 unique sequences which clustered into 121 distinct OTUs on the basis of our cut-off value of $>85 \%$ identity. 


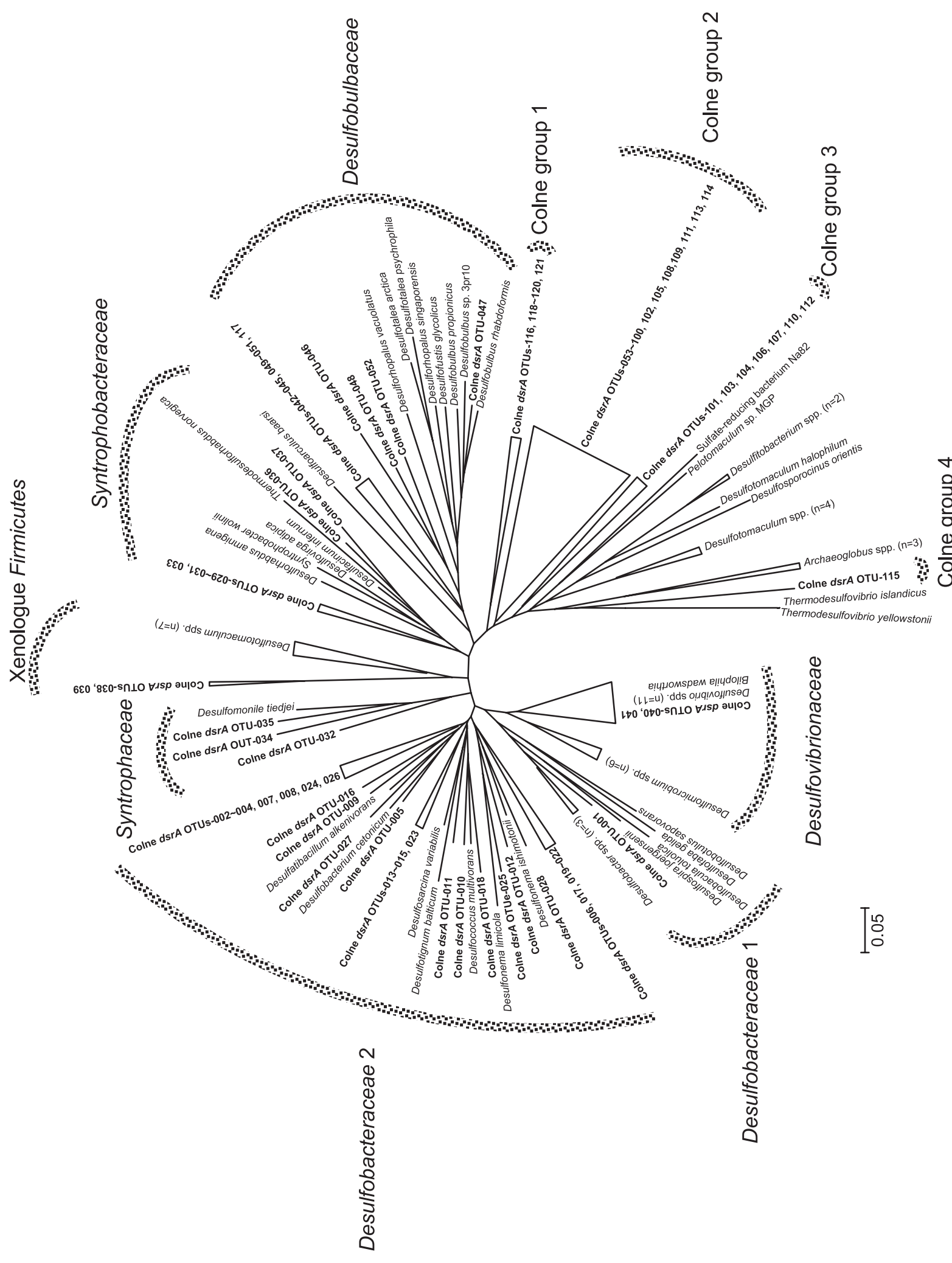


Table 1. Assignment of $d s r A$ clones from sediment samples of the Colne estuary

\begin{tabular}{|c|c|c|c|c|c|}
\hline \multirow{2}{*}{ Phylogenetic affiliations $^{\mathrm{a}}$} & \multirow{2}{*}{ Colne $d s r A$ OTU } & \multicolumn{4}{|c|}{ Number of clones in a library } \\
\hline & & Alresford Creek & The Hythe & East Hill Bridge & The Weir \\
\hline Desulfovibrionaceae group & 040,041 & 0 & 3 & 1 & 1 \\
\hline Desulfobacteraceae group 1 & 001 & 0 & 1 & 0 & 0 \\
\hline Desulfobacteraceae group 2 & $002 \sim 028$ & 52 & 61 & 37 & 16 \\
\hline Syntrophaceae group & $032,034,035$ & 1 & 0 & 0 & 2 \\
\hline Xenologues Firmicutes group & 038,039 & 0 & 0 & 2 & 5 \\
\hline Syntrophobacteraceae group & $029 \sim 031,033,036,037$ & 12 & 1 & 2 & 3 \\
\hline Desulfobulbaceae group & $042 \sim 052,117$ & 12 & 11 & 19 & 2 \\
\hline Colne group 1 & $116,118 \sim 121$ & 2 & 5 & 0 & 0 \\
\hline Colne group 2 & $053 \sim 100,102,105,108,109,111,113,114$ & 31 & 19 & 27 & 9 \\
\hline Colne group 3 & $101,103,104,106,107,110,112$ & 0 & 0 & 6 & 4 \\
\hline Colne group 4 & 115 & 3 & 0 & 0 & 0 \\
\hline
\end{tabular}

${ }^{a}$ Affiliation of $d s r A$ clones as inferred from Fig. 1.
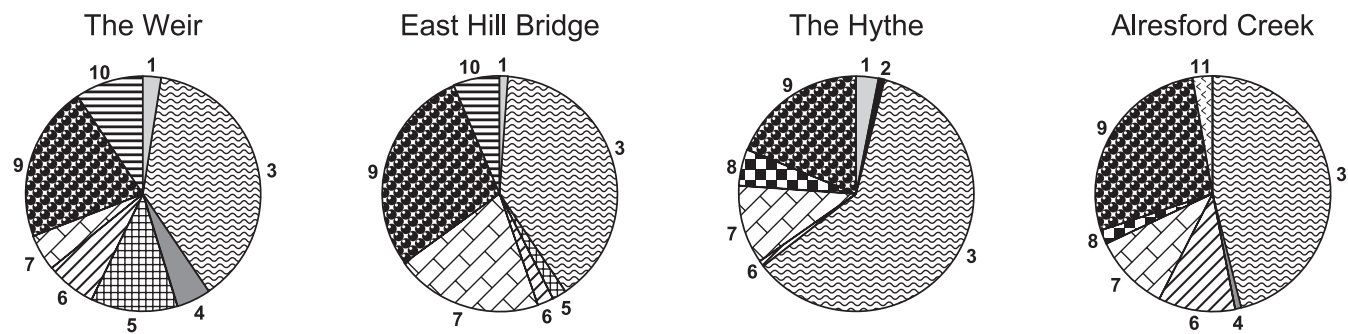

Increasing salinity

$\begin{array}{lll}\square \text { 1: Desulfovibrionaceae } \square \text { 4: Syntrophaceae } & \square \text { 7: Desulfobulbaceae } \quad \text { 目 10: Colne group } 3 \\ \text { 2: Desulfobacteraceae } 1 \quad \text { 5: Xenologue Firmicutes } & \text { 8: Colne group } 1 \quad \text { 圂 11: Colne group } 4 \\ \text { 3: Desulfobacteraceae } 2 & \square \text { 6: Syntrophobacteraceae }\end{array}$

Fig. 2. Spatial distribution of $d s r A$ clones at the four sites of the Colne estuary.

To obtain an accurate description of the phylogenetic relationship of the SRB population in sediment of the Colne estuary, we included in our analysis the most characterised sequences of pure SRB cultures available from the databases. Several phylogenetic approaches were taken to analyse the partial $d s r A$ sequences. Although differences in tree topology were obtained among these approaches, a similar ordering of taxa was found among the different phylogenetic analyses. Similar orders of taxa were also found between our partial $d s r A$ sequences and the entire $d s r A B$ operon $^{14,44}$. The neighbour-joining analysis revealed 11 lineages of cloned $d s r A$ sequences. Although some were related to cultured SRB, others almost certainly represent undescribed SRB (Fig. 1 and Table 1).
Nearly half of the clones recovered from all four sites (166 out of 350, see Fig. 2) were most closely related to members of Desulfobacteraceae group 2 such as Desulfobacterium, Desulfococcus, Desulfonema and Desulfosarcina (Fig. 1 and Table 1). These organisms completely oxidize a diverse range of organic compounds, including acetate and other short chain fatty acids, to $\mathrm{CO}_{2}$. Similar sequences have also been recovered from other marine and freshwater environments ${ }^{1,16,41)}$. Desulfosarcina has been reported to be numerically abundant in sediment of the German Wadden Sea ${ }^{25}$. Previous work on the Colne Estuary using 16S rRNA-targeted oligonucleotide probes to directly extracted RNA detected Desulfobacter and Desulfobacterium from the mouth of the estuary up to the brackish site at 
the Hythe ${ }^{28,31)}$. In sediment slurry microcosms from the River Colne estuary, sulphate-dependent acetate utilisation was linked to Desulfobacter at both the mouth of the estuary and the freshwater-dominated East Hill Bridge ${ }^{33)}$. Desulfobacter has been reported to be the predominant active SRB genus in marine-dominated estuarine sediments from $\mathrm{Japan}^{35)}$. Thus, it would appear that SRB related to complete oxidizers of the Desulfobacteraceae family are present and play an important role in anaerobic mineralisation along the length of the Colne estuary.

However, only a single clone related to Desulfobacter (Desulfobacteraceae group 1) was detected (from the Hythe). In some strains of Desulfobacter species, there are mismatches in the $d s r A$ primer regions ${ }^{15)}$ and so our PCR primers may not detect some Desulfobacter species.

The second most abundant group, Colne group 2 (86 sequences from all four sites), were phylogenetically distant from any isolated SRB group but were related to $d s r A B$ clones recovered from uncultured SRB in marine and freshwater environmental samples,3,21,41). This group is not closely related to any cultured SRB so its physiology cannot be inferred. Further study is required to isolate members of this group and to investigate whether they are active in these sediments.

Forty-four clones were related to members of the Desulfobulbaceae group which includes the incomplete oxidizing genera Desulforhopalus, Desulfotalea, Desulfofustis and Desulfobulbus. Cultured members of the Desulfobulbaceae can use alternatives to sulphate as electron acceptors, disproportionate sulphur and sulphur oxianions or grow by fermentation of lactate or ethanol in a sulphate-free medium $^{4,10,18)}$. In sediment slurry microcosms from the River Colne estuary, Desulfobulbus was linked to non-sulphate-dependent $\mathrm{H}_{2}$ consumption at the freshwater-dominated site, East Hill Bridge ${ }^{33)}$. Purdy et al. ${ }^{35)}$ have suggested that Desulfobulbus are ubiquitous in sediment and that this ubiquity is maintained by the physiological flexibility of members of this genus.

A group of $18 d s r A$ clones were phylogenetically related to Syntrophobacter wolinii and some new SRB genera, the Syntrophobacteraceae group. This diverse group of organisms includes complete and incomplete oxidizers from a number of different genera. The remaining 35 clones were found in six groups, three of which may represent novel organisms.

\section{Distribution of SRB groups in the Colne estuary}

The relative abundance of the 11 different groups in the libraries was calculated for all four samples (Fig. 2 and
Table 2. Comparison of the compositions of libraries from sediment samples collected at different sites in the Colne estuary

\begin{tabular}{lccc}
\hline & \multicolumn{3}{c}{$\begin{array}{l}\text { Sorensen similarity index (\%) for the library } \\
\text { from samples collected at the following site: }\end{array}$} \\
\cline { 2 - 4 } & The Hythe & EHB & The Weir \\
\hline Alresford Creek & 27.9 & 23.5 & 8.1 \\
& $(0.003,0.058)$ & $(0.001,0.001)$ & $(0.003,0.001)$ \\
The Hythe & & 26.5 & 8.5 \\
& & $(0.001,0.001)$ & $(0.024,0.001)$ \\
East Hill Bridge & & & 28.2 \\
(EHB) & & & $(0.089,0.889)$ \\
\hline
\end{tabular}

Values in parentheses are the probabilities that the compositions of the libraries were different, calculated by using the LIBSHUFF programme ( $\mathrm{X}$ compared to $\mathrm{Y}, \mathrm{Y}$ compared to $\mathrm{X}$, where $\mathrm{X}$ is the library indicated in the stub and $\mathrm{Y}$ is the library indicated in the column head).

Table 2). Four of these groups were detected at all four sites. Only one of these groups, Colne Group 2, was evenly distributed through the estuary. Clones from the Desulfobacteraceae group represented a greater proportion of the libraries at the more marine-dominated end of the estuary, as did clones from the Syntrophobacteraceae group, while clones related to the Desulfobulbaceae family were more abundant at the freshwater-dominated East Hill Bridge site than at the other three sites. Similar patterns can be seen in the six remaining groups but as only a few clones were detected in these groups, they may not reflect the true ecological distribution. Two of these groups, the xenologues Firmicutes group and Colne Group 3, were detected only at the freshwater-dominated East Hill Bridge and freshwater Weir sites while Colne group 1 was not detected at the freshwater end of the estuary. No more than three clones were detected at any site in each of the remaining three groups, the Desulfovibrionaceae group, the Syntrophaceae and Colne group 4.

Without clone library replication it is not possible to exclude the possibility that the distribution patterns seen among these four libraries are the result of sampling or stochastic artifacts. However, some of these distributions do confirm our present understanding of the ecology of some of these groups. Nedwell et al. ${ }^{28)}$ showed that the Desulfobacteraceae were the most important members of the active SRB community at both Arlesford and the Hythe, a result that the predominance of clones from this group at these two sites would support. The Desulfobulbaceae are known to be physiologically diverse, with strains capable of using alternatives to sulphate as electron acceptors, the disproportionation of sulphur and sulphur oxyanions and sulphatefree growth via fermentation. This physiological flexibility 


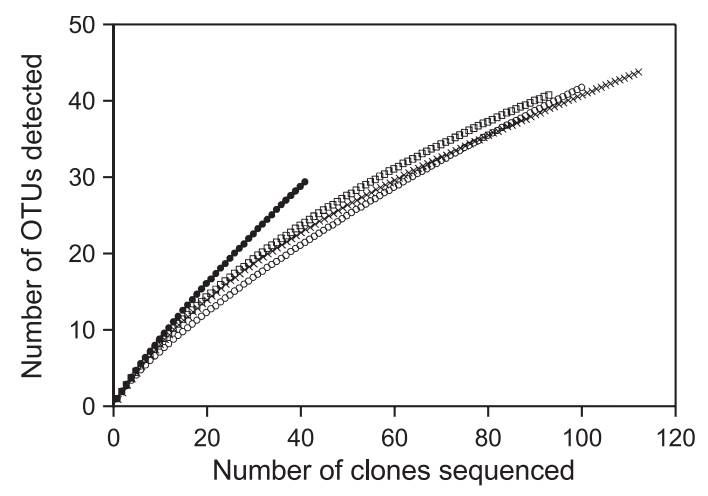

Fig. 3. Rarefaction curves generated for $d s r A$ in clone libraries from samples collected at Alresford Creek $(X)$, the Hythe $(\bigcirc)$, East Hill Bridge ( $\square)$ and the Weir (O).

may enable this group to exploit the varied conditions that exist at East Hill Bridge especially when a tidal incursion occurs. The relatively greater abundance of clones from the Syntrophobacteraceae group at Arlesford, the most marinedominated site sampled, is interesting as clones from this group were not detected at low salinity sites in a French estuary $^{19)}$ or a Japanese meromictic brackish lake ${ }^{16)}$. These three studies would suggest a marine bias for this group. Both the xenologues Firmiutes group and Colne group 3 have a freshwater distribution and are related to members of Desulfotomaculum, the Gram-positive SRB genus. These organisms have been described as growing best at low salt concentrations and thus seem to inhabit mainly freshwater environments or other aqueous environments with relatively low salt concentrations ${ }^{43}$. Through phylogenetic analyses of $d s r A B$ genes, sequences related to Desulfotomaculum were abundantly recovered from low saline environments ${ }^{2,3,19)}$.

Using the $85 \%$ similarity cut-off value, the coverage values that we obtained were 61, 58, 56 and 29\% for Alresford Creek, the Hythe, East Hill Bridge and the Weir, respectively, suggesting that the $d s r A$ sequences from the Weir sample were the most diverse. Analysis of the $d s r A$ clonal libraries using rarefaction curves supports this suggestion (Fig. 3). The Sorenson similarity index of the OTU populations in these libraries ranged from 8.1 to $28.2 \%$ (Table 2). LIBSHUFF analysis indicated that libraries from marine and brackish sites were significantly different to those from the freshwater sites. In these pairwise comparisons, neither the marine and brackish libraries nor the two freshwater libraries were significantly different (Table 2). High rates (76.2-105.7 $\mathrm{nmol} \mathrm{ml}^{-1} \mathrm{day}^{-1}$ ) of sulphate reduction were measured even in the low-sulphate environment at the Weir compared with those at high-sulphate sites of Alresford
Creek and the Hythe. Microbial sulphate reduction is a function of temperature as well as both electron donor and acceptor concentrations ${ }^{27,39)}$. In addition to the environmental factors, it is possible that the more diverse SRB community in the low-sulphate environment of the Weir site may maintain the high in situ rates of sulphate reduction.

Leloup et al. ${ }^{19)}$ showed that differences in sulphate concentration and salinity in two contrasting mudflats of a French estuary were reflected in the diversity of SRB. They showed that $\operatorname{ds} A B$ sequences related to Desulfotomaculum were dominant in the freshwater SRB community and $\delta$ proteobacterial $d s r A B$ sequences dominated at a brackish site, suggesting that sulphate availability and salinity play a significant role in structuring the SRB community in estuarine environments. In the Colne estuary, sulphate concentrations and salinity may influence the composition of SRB communities. However, organic carbon content and concentrations of inorganic nutrients in sediment samples of the Colne Rive estuary increase toward the top end of the estuary $^{13,30,42)}$ and these factors may also be responsible for the differences in the SRB communities along the estuary.

In conclusion, sequences of cloned $d s r A$ PCR products show the differential distribution of SRB groups in sediment along the Colne estuary. The complete oxidizers belonging to the Desulfobacteraceae family appear to be important in sulphur and carbon cycles in the estuary along with a deeply branched group in the $d s r A$ tree with no representatives from previously isolated SRB and the members of the Desulfobulbaceae family. The phylogenetic compositions of the $d s r A$ clone libraries differed from site to site, with significant differences between the marine/brackish and freshwater sediments. Therefore, the data presented here show a complex distribution of SRB along the estuary supporting the idea that salinity and sulphate concentrations are important factors in SRB community structure.

\section{Acknowledgements}

We thank T. Cresswell-Maynard and J. W. Green, University of Essex, for assistance in the field. This study was supported in part by Grants-in-Aid for Scientific Research (Nos. 15580170 and 17580169) from the Japan Society for the Promotion of Science and Fukui Prefectural Fund for the Promotion of Science to RK.

\section{References}

1) Bahr, M., B.C. Crump, V. Klepac-Ceraj, A. Teske, M.L. Sogin and J.E. Hobbie. 2005. Molecular characterization of sulfate- 
reducing bacteria in a New England salt marsh. Environ. Microbiol. 7: 1175-1185.

2) Castro, H., K.R. Reddy and A. Ogram. 2002. Composition and function of sulfate-reducing prokaryotes in eutrophic and pristine areas of the Florida Everglades. Appl. Environ. Microbiol. 68: 6129-6137.

3) Chang, Y.-J., A.D. Peacock, P.E. Long, J.R. Stephen, J.P. Mackinley, S.J. Macnaughton, A.K.M.A. Hussain, A.M. Saxton and D.C. White. 2001. Diversity and characterization of sulfate-reducing bacteria in groundwater at a uranium mill tailings site. Appl. Environ. Microbiol. 67: 3149-3160.

4) Finster, K., W. Liesack and B. Thamdrup. 1998. Elemental sulfur and thiosulfate disproportionation by Desulfocapsa sulfoexigens sp. nov., a new anaerobic bacterium isolated from marine surface sediment. Appl. Environ. Microbiol. 64: 119-125.

5) Felsenstein, J. 1985. Confidence limits on phylogenies: an approach using the bootstrap. Evolution 39: 783-791.

6) Fukui, M. and S. Takii. 1990. Seasonal variations of population density and activity of sulfate-reducing bacteria in offshore and reed sediments of a hypertrophic freshwater lake. Jpn. J. Limnol. 51: $63-71$.

7) Ingvorsen, K. and B.B. Jørgensen. 1984. Kinetics of sulphate uptake by freshwater and marine species of Desulfovibrio. Arch. Microbiol. 139: 61-66.

8) Ingvorsen, K., A.J.B. Zehnder and B.B. Jørgensen. 1984. Kinetics of sulphate and acetate uptake by Desulfobacter postgatei. Appl. Environ. Microbiol. 47: 403-408.

9) Ingvorsen, K., J.K. Zeikus and T.D. Brock. 1981. Dynamics of bacterial sulfate reduction in a eutrophic lake. Appl. Environ. Microbiol. 42: 1029-1036.

10) Janssen, P.H., A. Schuhmann, F. Bak and W. Liesack. 1996. Disproportionation of inorganic sulfur compounds by the sulfatereducing bacterium Desulfocapsa thiozymogenes gen. nov., sp. nov. Arch. Microbiol. 166: 184-192.

11) Jørgensen, B.B. 1978. A comparison of methods for the quantification of bacterial sulfate reduction in coastal marine sediments. I. Measurement with radiotracer techniques. Geomicrobiol. J. 1: $11-28$.

12) Jørgensen, B.B. 1982. Mineralization of organic matter in the sea-bed-The role of sulfate reduction. Nature 269: 643-645.

13) King, D. and D.B. Nedwell. 1987. The adaptation of nitratereducing bacterial communities in estuarine sediments in response to overlying nitrate loads. FEMS Microbiol. Ecol. 45 15-20.

14) Klein, M., M. Friedrich, A.J. Roger, P. Hugenholtz, S. Fishbain, H. Abicht, L.L. Blackall, D.A. Stahl and M. Wagner. 2001. Multiple lateral transfer of dissimilatory sulfite reductase genes between major lineages of sulfate-reducing prokaryotes. J. Bacteriol. 183: 6028-6035.

15) Kondo, R., D.B. Nedwell, K.J. Purdy and S.Q. Silva. 2004 Detection and enumeration of sulphate-reducing bacteria in estuarine sediments by competitive PCR. Geomicrobiol. J. 21: 145157.

16) Kondo, R., K. Osawa, L. Mochizuki, Y. Fujioka and J. Butani. 2006. Abundance and diversity of sulphate-reducing bacterioplankton in Lake Suigetsu, a meromictic lake in Fukui, Japan. Plankton Benthos Res. 1: 165-177.

17) Kumar, S., T. Tamura and M. Nei. 2004. MEGA3: Integrated software for Molecular Evolutionary Genetics Analysis and sequence alignment. Brief Bioinform. 5: 150-163.
18) Laanbroek, H.J., T. Abee and I.L. Voogd. 1982. Alcohol conversions by Desulfobulbus propionicus Lindhurst in the presence and absence of sulfate and hydrogen. Arch. Microbiol. 133: 178184.

19) Leloup, J., L. Quillet, T. Berthe and F. Petit. 2006. Diversity of the $\operatorname{ds} A B$ (dissimilatory sulfite reductase) gene sequences retrieved from two contrasting mudflats of the Seine estuary, France. FEMS Microbiol. Ecol. 55: 230-238.

20) Li, J.-H., K.J. Purdy, S. Takii and H. Hayashi. Seasonal changes in ribosomal RNA of sulfate reducing activity in a freshwater lake sediment. FEMS Microbiol. Ecol. 28: 31-39.

21) Loy, A., K. Küsel, A. Lehner, H.L. Drake and M. Wagner. 2004. Microarray and functional gene analyses of sulfate-reducing prokaryotes in low-sulfate, acidic fens reveal cooccurrence of recognized genera and novel lineages. Appl. Environ. Microbiol. 70: 6998-7009.

22) Maeda, H. and A. Kawai. 1988. Hydrogen sulfide production in bottom sediments in the Northern and Southern Lake Biwa. Nippon Suisan Gakkaishi. 54: 1623-1633.

23) Magurran, A.E. 1988. Ecological diversity and its measurement. Princeton University Press. Princeton, N.J.

24) Mullins, T.D., T.B. Britschgi, R.L. Krest and S.T. Giovannoni. 1995. Genetic comparisons reveal the same unknown bacterial lineages in Atlantic and Pacific bacterioplankton communities. Limnol. Oceanogr. 40: 148-158.

25) Mußmann, M., K. Ishii, R. Rabus and R. Amann. 2005. Diversity and vertical distribution of cultured and uncultured Deltaproteobacteria in an intertidal mud flat of the Wadden Sea. Environ. Microbiol. 7: 405-418.

26) Nedwell, D.B. 1984. The input and mineralization of organic carbon in anaerobic aquatic sediments. Adv. Microbiol. Ecol. 7: 93131.

27) Nedwell, D.B. and J.W. Abram. 1979. Relative influence of temperature and electron donor and electron acceptor concentrations on bacterial sulfate reduction in saltmarsh sediment. Microb. Ecol. 5: 67-72.

28) Nedwell, D.B., T.M. Embley and K.J. Purdy. 2004. Process rates and phylogenetic analysis of the sulphate reducing bacterial communities along an estuarine gradient. Aquat. Microb. Ecol. 37: 209-217.

29) Nedwell, D.B. and S. Takii. 1988. Bacterial sulphate reduction in sediments of European salt marsh: Acid-volatile and tin-reducible products. Estuar. Coast. Shelf Sci. 26: 599-606.

30) Ogilvie, B., D.B. Nedwell, R.M. Harrison, A. Robinson and A. Sage. 1997. High nitrate, muddy estuaries as nitrogen sinks: the nitrogen budget of the River Colne estuary (United Kingdom). Mar. Ecol. Prog. Ser. 150: 217-228.

31) Purdy, K.J., T.M. Embley and D.B. Nedwell. 2002. The distribution and activity of sulphate reducing bacteria in estuarine and coastal marine sediments. Antonie van Leewenhoek 81: 181-187.

32) Purdy, K.J., T.M. Embley, S. Takii and D.B. Nedwell. 1996. Rapid extraction of DNA and rRNA from sediments by a novel hydroxyapatite spin-column method. Appl. Environ. Microbiol. 62: 3905-3907.

33) Purdy, K.J., M.A. Munson, T. Cresswell-Maynard, D.B. Nedwell and T.M. Embley. 2003. Use of 16S rRNA-targeted oligonucleotide probes to investigate function and phylogeny of sulphatereducing bacteria and methanogenic archaea in a UK estuary. FEMS Microbiol. Ecol. 44: 361-371.

34) Purdy, K.J., M.A. Munson, D.B. Nedwell and T.M. Embley. 
2002. Comparison of the molecular diversity of the methanogenic community at the brackish and marine ends of a UK estuary. FEMS Microbiol. Ecol. 39: 17-21.

35) Purdy, K.J., D.B. Nedwell, T.M. Embley and S. Takii. 2001. Use of 16S rRNA-targeted oligonucleotide probes to investigate the distribution of sulphate-reducing bacteria in estuarine sediments. FEMS Microbiol. Ecol. 36: 165-168.

36) Singleton, D., M.A. Furlong, S.L. Rathbun and W.B. Whitman. 2001. Quantitative comparisons of 16S rRNA gene sequence libraries from environmental samples. Appl. Environ. Microbiol. 67: 4374-4376.

37) Smith, R.L. and M.J. Klug. 1981. Reduction of sulfur compounds in the sediment of a eutrophic lake basin. Appl. Environ. Microbiol. 41: 1230-1237.

38) Takii, S. and M. Fukui. 1991. Relative importance of methanogenesis, sulfate reduction and denitirification in sediments of the lower Tama River. Bull. Jpn. Soc. Microb. Ecol. 6: 1-8.

39) Takii, S., H. Tanaka, K. Kohata, Y. Nakamura, H. Ogura and S. Takeshita. 2002. Seasonal changes in sulfate reduction in sediments in the inner part of Tokyo Bay. Microbes Environ. 17: 10 17.
40) Thompson, J.D., T.J. Gibson, F. Plewniak, F. Jeanmougin and D.G. Higgins. 1997. The Clustal X windows interface: flexible strategies for multiple sequence alignment aided by quality analysis tools. Nucleic Acids Res. 25: 4876-4882.

41) Thomsen, T.R., K. Finster and N.B. Ramsing. 2001. Biogeochemical and molecular signatures of anaerobic methane oxidation in a marine sediment. Appl. Environ. Microbiol. 67: 16461656.

42) Thornton, D.C.O., L.F. Dong, G.J.C. Underwood and D.B. Nedwell. 2002. Factors affecting microphytobenthic biomass, species composition and production in the Colne estuary (UK). Aquat. Microb. Ecol. 28: 285-300.

43) Widdel, F. 1992. The genus Desulfotomaculum, pp. 1792-1799. In A. Balows, H.G. Trüper, M. Dworkin, W. Harder and K.-H. Schleifer (ed.), The prokaryotes: a handbook on the biology of bacteria: ecophysiology, identification, Application. 2nd edn. Springer-Verlag, New York.

44) Zverlov, V., M. Klein, S. Lüker, M.W. Friedrich, J. Kellermann, D.A. Stahl, A. Loy and M. Wagner. 2005. Lateral gene transfer of dissimilatory (bi)sulfite reductase revisited. J. Bacteriol. 187: 2203-2208. 